\title{
Oxalate-Induced and Cell-Cycle-Dependent Expression of Nuclear Pore Complex Oxalate Binding Protein gp210
}

\author{
R. Vijaya, M. Kannapiran, ${ }^{1}$ and R. Selvam ${ }^{2}$ \\ Department of Medical Biochemistry, Dr. Alm Post Graduate Institute of Basic Medical Sciences, \\ University of Madras, Taramani Campus, Chennai 600113, India
}

Received October 25, 1999

The effect of oxalate, a constituent of renal stone, on the expression of nuclear pore complex oxalate binding protein (gp210) in Vero monkey kidney cells was examined. The expression of this protein was found to increase more in mitotic phase than in $\mathbf{S}$ phase, suggesting cell cycle dependency. Exposure of cells to oxalate-containing growth medium resulted in a relative increase in nuclear pore complex oxalate binding protein in each stage of cell cycle. The concentration of this protein was found to increase six times in the telophase stage of the cells exposed to high concentrations of oxalate in the growth medium, though slight reduction in cell density was observed. Structural analogues of oxalate did not show any stimulatory effect on expression of this oxalate binding protein. Hence, the expression of the nuclear pore complex oxalate binding protein gp210 was specific to oxalate and is cell cycle dependent. $\odot 1999$ Academic Press

Key Words: oxalate binding protein, nuclear pore complex; gp210; cell cycle.

Urolithiasis is a process of biomineralixation in the urinary tract. Perturbations in renal oxalate handling play a major role in renal stone disease (1). Our earlier studies have shown the presence of about $70 \%$ of total oxalate binding to nuclei while only $30 \%$ binding to the mitochondria $(2,3)$. Our earlier studies have reported the presence of oxalate binding protein in the nuclear envelope (4). Our preliminary studies have shown that the nuclear pore complex protein gp210 is an oxalate binding protein (5). Oxalate has been shown to induce mitosis (6), DNA synthesis (7), and expression of certain genes (8). The physiological significance of the presence of oxalate binding protein in the nuclear pore complex is not well understood. In order to study its functions, the expression of this protein during different stages of cell cycle was studied in the presence of oxalate.

\footnotetext{
${ }^{1}$ Tuberculosis Research Centre, Chetpet, Chennai.

2 To whom correspondence. should be addressed. Fax: 91-44 4926709. E-mail: pgibms@md2.vsnl.net.
}

\section{MATERIALS AND METHODS}

Minimum essential medium, penicillin, streptomycin, sodium bicarbonate, fetal calfserum, methotrexate, colchicin, Cytochalasin B, trypsin-EDTA solution, and molecular weight markers were obtained from Sigma Chemical Company, St. Louis, Missouri. Sodium oxalate, oxamate, malate, citrate. and other chemicals were purchased from Sisco Research Laboratories, Mumbai. Other chemicals used were of analytical grade and purity.

Human primary biliary cirrhosis (PBC) serum containing autoantibodies against nuclear pore complex protein gp210 was a gift from Professor Howard J. Worman, Columbia University, New York (9). Goat anti-human IgG horseradish peroxidase was a gift from NII, New Delhi.

Cell line and cell culture. Vero monkey kidney cells were serially passaged in minimal essential medium (MEM) supplemented with $10 \%$ fetal calf serum, penicillin $(100 \mathrm{U} / \mathrm{ml})$, and streptomycin (100 $\mu \mathrm{g} / \mathrm{ml})$. The cells were maintained in an atmosphere of $5 \% \mathrm{CO}_{2} / 95 \%$ air in a humidified $37^{\circ} \mathrm{C}$ incubator.

Oxalate concentration. Oxalate concentration in the medium was fixed according to (10) to be $0.1 \mathrm{mM}$ (low), $0.3 \mathrm{mM}$ (medium), and 1 $\mathrm{mM}$ (high/toxic) total oxalate (which is equivalent to 30,100 , and 350 $\mu \mathrm{M}$ free oxalate concentrations, respectively). $1 \times 10^{5}$ cells were incubated with MEM containing specified concentrations of oxalate.

Synchronization at different stages of cell cycle. $1 \times 10^{5}$ cells were incubated with MEM containing corresponding cell cycle blockers in 25 -ml culture flasks. Cells were synchronized at $\mathrm{S}$ phase using 10 $\mu \mathrm{g} / \mathrm{ml}$ methotrexate, at mitotic phase (metaphase) using $10 \mu \mathrm{g} / \mathrm{ml}$ colchicin, and at mitotic phase (telophase) using $10 \mu \mathrm{g} / \mathrm{ml}$ Cytochalasin B and the cells were allowed to synchronize for $24 \mathrm{~h}$.

Substrate analogues. $1 \times 10^{5}$ cells were incubated with MEM containing $0.1 \mathrm{mM}$ oxalate, malate, succinate and citrate and grown for $24 \mathrm{~h}$.

Trypsinization. Cells were trypsinized by incubating with trypsin-EDTA solution for 20 minutes, and washed two times by centrifuging at $2500 \mathrm{rpm} / 10$ minutes with MEM and resuspended with the same.

Assessment of cell density. From the resuspended pellet, an aliquot of the cell was mixed with $0.05 \%$ trypan blue. Cells were then examined immediately under a light microscope and the relative abundance of the dead (stained) cells was assessed.

Whole cell extract. Whole cell extract was prepared according to the method of (11). The cells resuspended in MEM was centrifuged at $2500 \mathrm{rpm} / 5$ minutes end resuspended in the lysis buffer $(100 \mathrm{mM}$ Tris-HCl, $\mathrm{pH} 7.4$, containing $1 \%$ Triton X-100, 0.4\% SDS and $2 \mathrm{mM}$ EDTA) and incubated for 30 minutes at $4^{\circ} \mathrm{C}$. The Triton X-100 extract containing the nuclear pore complex protein was obtained by centrifuging the whole cell extract at 15,000 rpm/30 minutes. Protein 
TABLE 1

Effect of Oxalate on Cell Density

\begin{tabular}{cc}
\hline Particulars & \% of cell density \\
\hline $0.1 \mathrm{mM}$ Oxalate & +25 \\
$\mathbf{0 . 3} \mathrm{mM}$ Oxalate & $\mathbf{+ 4 0}$ \\
$1.0 \mathrm{mM}$ Oxalate & -10
\end{tabular}

Note. +, Increase; -, decrease. Values are means of 3 experiments with 2 replicates in each experiment. 1 x $10^{5}$ cells were incubated with growth medium containing varying concentrations of oxalate. After $24 \mathrm{~h}, 10 \mu \mathrm{l}$ of cells from each category was mixed with $0.05 \%$ trypan blue and the cell density was assessed as described under Materials and Methods.

concentration was estimated by the method of (12) in the Triton $\mathrm{X}-100$ extract and in the residual pellet.

ELISA. Enzyme-linked immunosorbent assay was done according to the method of (13). $30 \mu \mathrm{g}$ of Triton extract and residual pellet were coated on 96-well microtitre plates, probed with 1:500 diluted PBC serum containing autoantibodies against nuclear pore complex protein gp210, and then incubated with 1:20,000 diluted secondary antibody (goat anti-human IgG horseradish peroxidase). TMB/ $\mathrm{H}_{2} \mathrm{O}_{2}$ was added and incubated in dark. The color developed on adding $1 \mathrm{~N}$ $\mathrm{H}_{2} \mathrm{SO}_{4}$ was read at $540 \mathrm{~nm}$ on a MR600 Dynatech ELISA reader.

The total gp210 concentration $\left(\mu \mathrm{g} / 1 \mathbf{x} 10^{5}\right)$ was calculated from $\boldsymbol{a}$ standard curve obtained by coating varying concentrations of isolated human kidney gp210 (1-10 $\mathrm{gg}$ ) on 96-well microtitre ELISA plates and probing with $\mathrm{PBC}$ serum (1:500) containing gp210 autoantibodies and proceeded as for ELISA.

SDS-PAGE. Triton extracts of unsynchronized and synchronized cells in the presence of $0.1,0.3$, and $1.0 \mathrm{mM}$ oxalate were electrophoresed on an $8 \%$ mini-gel along with molecular weight markers ranging from 21 to $205 \mathrm{kDa}$ (14) and silver stained by the method of (15).

Statistical analysis. All biochemical values were expressed as means \pm SD of 3 experiments with 2 replicates in each experiment. The $P$ significance was arrived at using Student's $t$ test $\left(P<0.05^{*}\right.$; $\left.P<0.01^{* *} ; P<0.001^{* * *}\right)$.

\section{RESULTS}

\section{Effect of Oxalate on Cell Density}

Exposure of VERO cells to oxalate in the culture medium produced changes in cell density. $24 \mathrm{~h}$ of exposure to varying concentrations $(0.1,0.3$, and $1.0 \mathrm{mM}$ total oxalate) of oxalate produced biphasic effects on cell numbers. Cells exposed to $0.1 \mathrm{mM}$ total oxalate showed $25 \%$ increase in cell density, cells exposed to $0.3 \mathrm{mM}$ total oxalate showed $40 \%$ increase in cell density, and those exposed to $1.0 \mathrm{mM}$ total oxalate showed a slight decline of $10 \%$ in cell density compared to that of the control cells unexposed to oxalate (Table 1).

\section{Effect of Oxalate on the Expression of gp210}

When the Triton extract of cells grown in $0.1,0.3$, and $1.0 \mathrm{mM}$ total oxalate were quantitated for gp210 concentration by ELISA, there was a significant increase of $63 \%(\mathrm{P}<0.01), 155 \%(\mathrm{P}<0.01)$, and $450 \%$

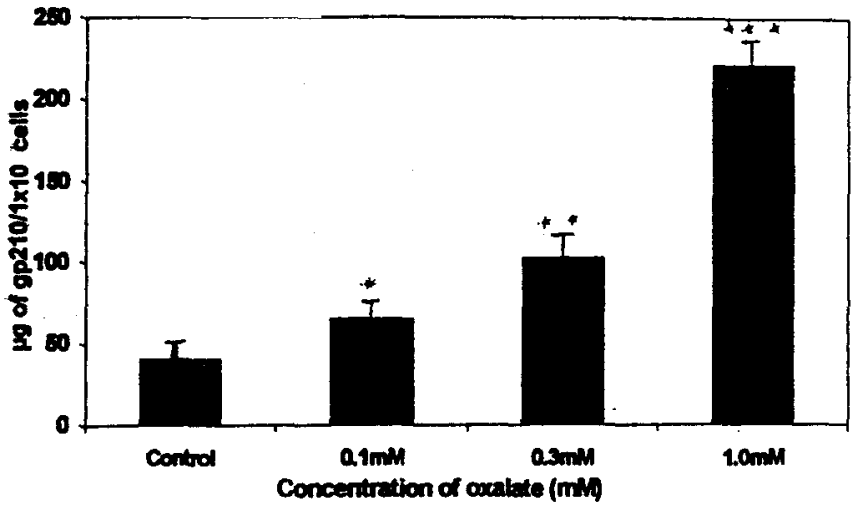

FIG. 1. Effect of oxalate on expression of gp210. Values are means \pm SD of 3 experiments with 2 replicates for each experiment. $30 \mu \mathrm{g}$ of Triton extract was coated onto ELISA plates and probed with PBC serum containing gp210 autoantibodies (1:500) and the gp210 concentration was determined as described under Materials and Methods. Values are statistically significant compared to control $\left(P<0.05^{*} ; P<0.01^{* *} ; P<0.001^{* * *}\right)$.

$(P<0.001$ ), respectively (Fig. 1 ). The residual pellet showed no presence of gp210.

\section{Oxalate Induced and Cell-Cycle-Dependent Expression of gp210}

By ELISA. The concentration of gp210 in synchronized cells grown in the medium containing different concentrations of oxalate showed an increase compared to that of the control cells unexposed to oxalate (Fig. 2).

In the $\mathrm{S}$ phase, cells exposed to $0.1,0.3$, and $1.0 \mathrm{mM}$ total oxalate showed a significant increase of $83 \%(P<$ $0.05), 152 \%(P<0.01)$, and $213 \%(P<0.001)$ of gp210 concentration respectively compared to that of the control $\mathrm{S}$ phase cells unexposed to oxalate.

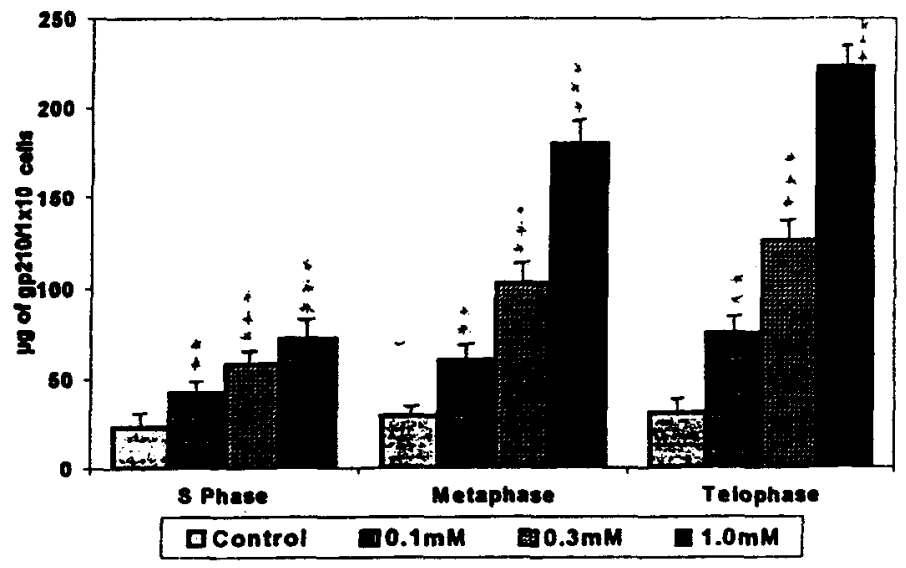

FIG. 2. Oxylate-induced and cell-cycle-dependent expression of gp210. Values are means \pm SD of 3 experiments with 2 replicates for each experiment. $30 \mu \mathrm{g}$ of Triton extract was coated onto ELISA plates and probed with PBC serum containing gp210 autoantibodies (1:500) and the gp210 concentration was determined as described under Materials and Methods. Values are statistically significant compared to control ( $\left.P<0.05^{*} ; P<0.01^{* *} ; P<0.001^{* * *}\right)$. 


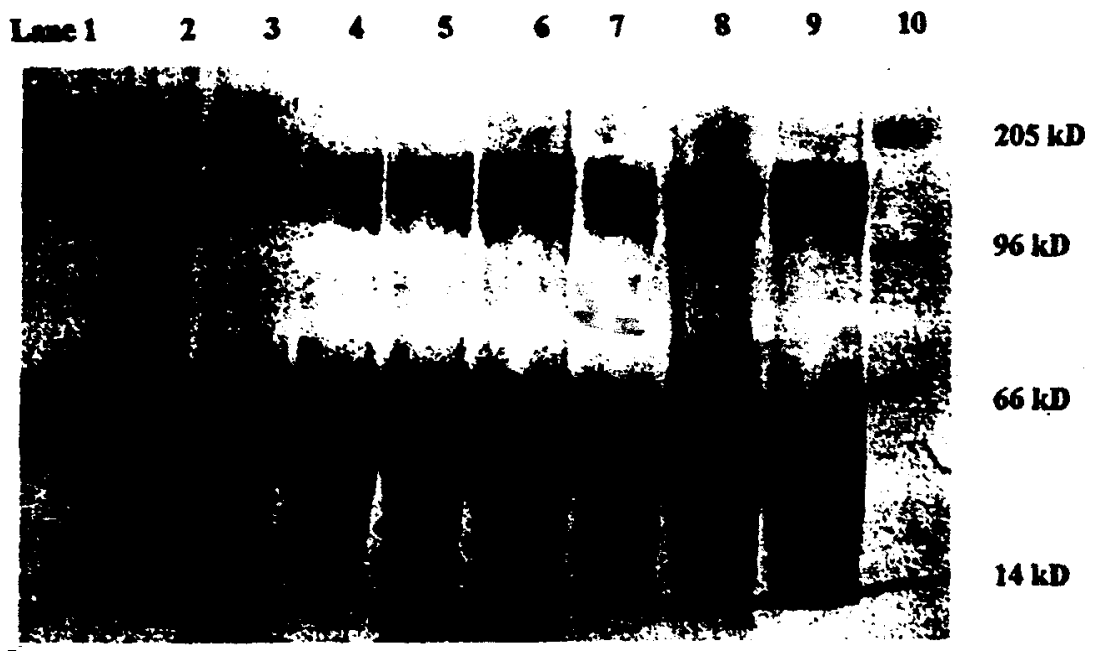

FIG. 3. SDS-PAGE profile of oxalate induced and cell cycle-dependent expression of gp210. Lane 1: S phase cells exposed to 0.1 mM oxalate. Lane 2: S phase cells exposed to $0.3 \mathrm{mM}$ oxalate. Lane 3: S phase cells exposed to $1.0 \mathrm{mM}$ oxalate. Lane 4: Metaphase cells exposed to $0.1 \mathrm{mM}$ oxalate. Lane 5: Metaphase cells exposed to $0.3 \mathrm{mM}$ oxalate. Lane 6: Metaphase cells exposed to $1.0 \mathrm{mM}$ oxalate. Lane 7: Telophase cells exposed to $0.1 \mathrm{mM}$ oxalate. Lane 8: Telophase cells exposed to $0.3 \mathrm{mM}$ oxalate. Lane 9: Telophase cells exposed to $1.0 \mathrm{mM}$ oxalate. Lane 10: Molecular weight markers. $50 \mu \mathrm{g}$ of Triton extract of cells was electrophoresed on $8 \%$ mini-gel along with molecular weight markers and silver stained as described under Materials and Methods.

In the mitotic phase, cells exposed to $0.1,0.3$, and 1.0 $\mathrm{mM}$ total oxalate and synchronized at metaphase showed a significant increase of $107 \%(\mathrm{P}<0.01)$, $252 \%(\mathrm{P}<0.01)$, and $520 \%(\mathrm{P}<0.001)$ of $\mathrm{gp} 210$ concentration respectively compared to that of the control metaphase cells unexposed to oxalate. The cells synchronized at telophase and exposed to $0.1,0.3$, and $1.0 \mathrm{mM}$ total oxalate concentration showed a significant increase of $142 \%(P<0.001), 306 \%(P<0.001)$, and $620 \%(P<0.001)$ of gp210 concentration compared to that of the control telophase cells unexposed to oxalate. Telophase cells exposed to $1.0 \mathrm{mM}$ total oxalate concentration showed the maximum concentration of gp210.

SDS-PAGE. The Triton extracts of synchronized cells grown in different concentrations of oxalate were electrophoresed on 8\% SDS-PAGE along with molecular weight markers. Relatively thicker bands were observed in telophase cells with increase in oxalate concentration (Fig. 3).

\section{Effect of Substrate Analogues}

When cells grown with $0.1 \mathrm{mM}$ oxalate or its structural analogues-oxamate, malate, succinate, and citrate-were checked for gp210 concentration, only cells grown with oxalate showed a significant increase of $63 \%(P<0.01)$ of gp210 concentration, while others did not show any significant increase in gp210 concentration (Fig. 4).

\section{DISCUSSION}

In our earlier studies, we have shown that nuclear oxalate binding activity is associated with the nuclear pore complex protein gp210. The physiological importance of this activity with gp210 is not clear. Oxalate has been shown to induce mitosis (6) while gp210 is also reported to be involved in cell cycle (16). In order to understand the role of gp210 during cell cycle, the expression of this oxalate binding protein during oxalate stress condition has been determined.

Lower concentrations of oxalate increase the cell density while at higher concentration, a slight decline in cell density is observed. Available evidence suggests that oxalate levels are about $5-10 \mu \mathrm{M}$ in the glomerular filtrate (17) and would increase to $50-100 \mu \mathrm{M}$ in the proximal tubules. Cortical oxalate levels might reach approximately $300 \mu \mathrm{M}$ free oxalate concentra-

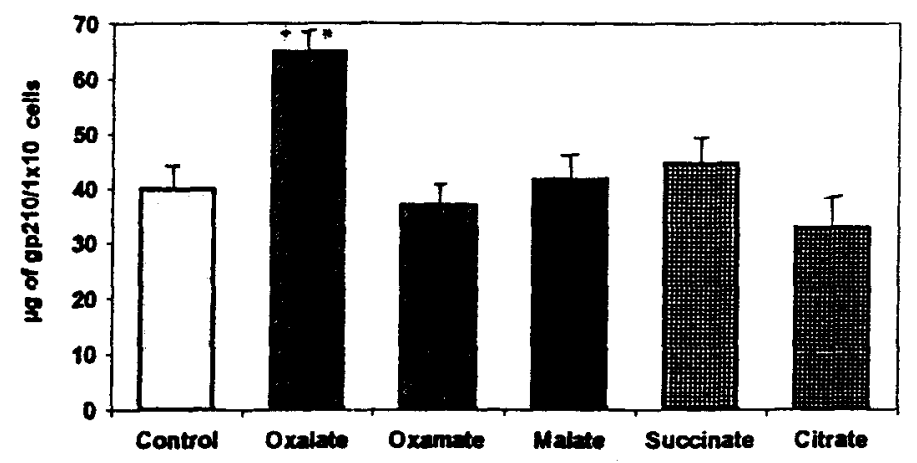

FIG. 4. Effect of substrate analogues on expression of gp210. Values are means \pm SD of 3 experiments with 2 replicates for each experiment. $30 \mu \mathrm{g}$ of Triton extract was coated onto ELISA plates and probed with PBC serum containing gp210 autoantibodies (1:500) and the gp210 concentration was determined as described under Materials and Methods. Values are statistically significant compared to control $\left(P<0.01^{* *}\right)$. 
tion (18). Thus, oxalate might well approach toxic levels in the proximal tubules, particularly in individuals with hyperoxaluria. High concentrations of oxalate (1.0 $\mathrm{mM}$ total oxalate) are toxic to LLC-PKl cells, a line of renal epithelial cells (10). However, in our study, the cells exposed to higher concentration of oxalate $(1.0$ $\mathrm{mM}$ total oxalate) have shown an increase in gp210 concentration suggesting an induction of its expression by oxalate. Further its expression is specific only for oxalate since its structural analogues show no induction of gp210 expression.

Though the expression of gp210 is increased at each stage of the cell cycle on exposure to different concentrations of oxalate, the maximal expression of gp210 is found to be in mitosis (6-fold) rather than in interphase (2-fold). Gp210 is involved in targeting the pore proteins (19) to facilitate the formation of the pore complex (20) and also anchors (21) the pore complex during telophase. Many of the structural modifications of the cellular architecture that take place in mitosis, including nuclear envelope breakdown, occur concurrently with protein phosphorylation $(22,23)$. As gp210 is expressed more in mitosis during oxalate stress condition, it is suggested that oxalate plays a significant role in targeting gp210 towards reassembly of nuclear envelope for the new daughter cells. As oxalate has been shown to have mitogenic effect (6), the cell proliferation may be associated with the induction of gp210. In addition, oxalate is shown to induce the expression of $c$-myc gene (8), and calcium oxalate crystals have been shown to induce the expression of immediate early genes c-myc, c-jun, EGR-1 and NVR-77 and genes encoding plasminogen activator (PAI-1) (24) and plateletderived growth factor (PDGF)-A in BAC-1 kidney epithelial cells in primary cultures of rat proximal tubular epithelium on exposure to oxidative stress (25).

Under oxalate stress conditions, the intracellular oxalate concentration is very high (26) and nuclei contain $2 / 3$ of total oxalate (2). The presence of an oxalate binding protein in the pore complex may be very significant for the accumulation of oxalate in nuclei. Further, oxalate is shown to bind histone HIB and has been suggested to be involved with transcription (27). Hence, it is concluded that oxalate induces the expression of the nuclear pore complex oxalate binding protein gp210 in cell cycle processes.

\section{ACKNOWLEDGMENT}

R.V. was a recipient of a Senior Research Fellowship from the Council of Scientific and Industrial Research (CSIR), New Delhi.

\section{REFERENCES}

1. Sigmon, D., Kumar, S., Carpenter, B., Miller, T., Menon, M., and Scheid, C. (1991) Am. J. Kid. Dis. 27, 376-380.

2. Selvam, R., and Menon, M. (1983) II National Conference on Urolithiasis, Trivandrum, Paper No. 55.

3. Laxmanan, S., Selvam, R., Mahle, C. J., and Menon, M. (1986) J. Urol. 135, 862-865.

4. Selvam, R., Angayarkanni, N., and Vijaya, R. (1996) Med. Sci. Res. 24, 267-269.

5. Vijaya, R., and Selvam, R. (1999) Proceedings of the 8th European Symposium on Urolithiasis, June 9-12, Italy.

6. Li, Y., Sattler, G. L., and Pitot, H. C. (1993) Biochem. Bioohvs. Res. Commun. 193, 1339-13461

7. Koul, H., Kennington, L., Nair, G., Honeyman, T., Menon, M., and Scheid, C. (1994) Biochem Biophys. Res. Commun. 205, 1632-1637.

8. Koul, H., Kennington, L., Honeyman, T., Jonassen, J., Reddy, P.-V., Menon, M., and Scheid, C. (1996) Proceedings of the VIII International Symposium on Urolithiasis, Sep. 22-Oct. 2, Dallas, Texas, USA.

9. Nickowitz, R. E., and Worman, H. J. (1993) J. Exp. Med. 178, 2237-2242.

10. Scheid, C., Koul, H., Hill, W. A., Luber-Narod, J., Jonassen, J., Honeyman, T., Kennington, L., Kohli, R., Hodapp, J., Ayvazian, P., and Menon, M. (1996) J. Urol. 155, 1112-1116.

11. Brizuela, L., Draetta, G., and Beach, D. (1987) EMBO J. 6, 3507-3514.

12. Lowry, O. H., Rosenbrough, N. J., Farr, A. C., and Randall, R. J. (1951) J. Biol. Chem. 193, 265-275.

13. Sharma, M., and Singh, O. (1989) Immumoassays. in Murine and Human Monocional Antibodies: Production, Purification and Applications. Practical manual, National Institute of Immunology, New Delhi, pp. 27-29.

14. Laemmli, U. K. (1970) Nature 227, 680-685.

15. Peter. J. (1990) Electrophoretic and immunoblotting methods. in Peptide Hormone Secretion-A Practical Approach (Hutton. J. C., and Siddle, K., Eds.), pp. 42-44, IRL Press, London.

16 Favreau, C.. Worman, H. J., Wozniak, R. W., Frappier, T., and Courvalin, J.-C. (1996) Biochemistry 35, 8035-8044.

17. Wolthers, B. G., and Hayer, M. (1982) Clin. Chim. Acta 120, 87.

18. Knight, T. F., Sansom, S. C., Senekjian. H. O., and Weinman. E. J. (1981) Am. J. P'hysiol. 240, F295-F298.

19. Choudhary, N., and Courvalin, J.-C. (1993) J. Cell Biol. 122, 295-306.

20. Von Heijne, G. (1986) Nucleic Acids Res. 14, 4683-4690.

21. Gerace, L., Ottaviano, Y., and Kondor-Koch, C. (1982) J. Cell Biol. 95, 826-837.

22. Nurse (1990) Nature (London) 344, 503-508.

23. Favreau, C., Worman, H. J., Wozniak, R. W., Frappier, T., and Courvalin, J.-C. (1996) Biochem. 35, 8035-8044.

24. Hammes, M. S., Leiske. J. C., Pawar, S., Keeley, E., and Toback, F. G. (1994) J. Am. Soc. Nephrol. 5, 8044-8648.

25. Menon, M., Ayuvayain, P., Hodapp, J., Malhotra, R., Renzulli, L., Scheid, C., and Koul, H. (1993) J. Urol. 149, 440A.

26. Baskar, K., and Selvam, R. (1985) Arogya-J. Health Science XI, 48-54.

27. Selvam, R., and Kannabiran, K. (1996) J. Urol. 156, 237-242. 